\title{
UJI AKTIVITAS PENGHAMBATAN ENZIM $\alpha$-GLUKOSIDASE EKSTRAK ETANOL BIJI BUAH ALPUKAT SANGRAI (Persea americana Mill.) SECARA IN VITRO
}

\author{
St. Maryam, Asriani Suhaenah, Nurul Fadhillah Amrullah \\ Fakultas Farmasi, Universitas Muslim Indonesia, Makassar \\ Email : st.maryam@umi.ac.id
}

\begin{abstract}
It is known that the seeds of avocado (Persea americana Mill.) are one part of the avocado widely used to treat various diseases, including diabetes. Based on the previous research, avocado seeds contain flavonoids with the potency as inhibitors of the enzyme a-glucosidase. The research aimed to determine the potency of ethanol extracted by meceration using $96 \%$ ethanol. The inhibitory activity was assayed using ELISA (Enzyme-Linked Immunosorbant Assay) reader measured at the wavelength of 405 with an acarbose comparator. The results showed that the ethanol extract of avocado seeds had an inhibitory activity included in the active category based on $I C_{50}$ value of $34.300 \mu \mathrm{g} / \mathrm{mL}$. Meanwhile, the acarbose had inhibition activity included in the very active category with an IC 50 value of $0.253 \mu \mathrm{g} / \mathrm{mL}$.
\end{abstract}

Key word: Avocado seeds (Persea americana Mill.), enzyme a-glucosidase, ELISA (Enzyme-Linked Immunosorbant Assay) reader.

\section{PENDAHULUAN}

Diabetes berasal dari bahasa Yunani berarti "mengalirkan atau mengalihkan" (shipon). Melitus berasal dari bahasa Latin yang bermakna manis atau madu. Penyakit diabetes melitus (DM) dapat diartikan individu yang mengalirkan volume urin yang banyak dengan kadar glukosa tinggi. ${ }^{1}$ Penyebab dari penyakit diabetes melitus yaitu adanya gangguan metabolisme karbohidrat, lipid dan protein akibat gangguan sekresi insulin oleh sel-sel $\beta$ Langerhans kelenjar pankreas, aksi insulin terhadap jaringan target yang mengakibatkan insensitivitas sel terhadap insulin, ataupun keduanya. ${ }^{2}$

Dalam dunia pengobatan, alpukat telah banyak digunakan sebagai obat tradisional untuk mengobati berbagai macam penyakit, salah satunya yaitu pada bagian biji buah alpukat yang dapat digunakan untuk mengurangi kadar gula dalam darah. ${ }^{3}$ Dalam penelitian yang dilakukan Marlinda $(2012)^{3}$ mengenai skrining fitokimia dan uji aktivitas antidiabetes terhadap ekstrak etanol biji buah alpukat, hasilnya mengandung senyawa alkaloid, polifenol, tanin, flavonoid, triterpenoid, kuinon, saponin, monoterpen dan seskuiterpen serta dapat menurunkan kadar glukosa darah tikus.

Berdasarkan literatur, flavonoid merupakan golongan senyawa kimia yang memiliki penghambatan aktivitas a-glukosidase yang tinggi karena golongan senyawa tersebut termasuk senyawa polifenol ${ }^{4}$. Penelitian yang telah dilakukan oleh Tadera dkk (2006) ${ }^{5}$ telah membuktikan secara in vitro bahwa flavonoid merupakan senyawa yang berpotensi menghambat $\alpha$-glukosidase.

Senyawa-senyawa inhibitor $\alpha$ glukosidase bekerja menghambat enzim $\alpha$ glukosidase yang terdapat pada dinding usus halus. Enzim a-glukosidase berfungsi untuk menghidrolisis oligosakarida dan disakarida pada dinding usus halus. Inhibisi kerja enzim ini 
secara efektif dapat mengurangi pencernaan karbohidrat kompleks dan absorbsinya, sehingga dapat mengurangi peningkatan kadar glukosa postprandial pada penderita diabetes. ${ }^{6}$

Pada penelitian ini digunakan sampel berupa biji alpukat yang disangrai, berdasarkan penelitian dari Marlinda dkk $(2012)^{3}$ yang membandingkan biji alpukat kering dengan segar, biji alpukat kering lebih banyak mengandung flavonoid dibanding yang segar, oleh karena itu biji alpukat disangrai hingga benar-benar kering.

Secara empiris, pengolahan biji alpukat sebelum dihaluskan dapat dipanggang (oven) ataupun disangrai. Nurhjrah $(2016)^{7}$ melakukan pengujian penghambatan enzim $\alpha$ glukosidase menggunakan ekstrak metanol biji alpukat yang dikeringkan kemudian di oven, sedangkan pada penelitian ini dikeringkan kemudian di sangrai, hal ini dapat menjadi dasar perbandingan cara pengolahan biji alpukat yang paling baik dalam menurunkan kadar glukosa darah, sehingga dapat memberikan informasi kepada masyarakat tentang pengolahan biji alpukat sebagai antidiabetes.

Ekstrak diukur aktivitas penghambatan a-glukosidase menggunakan substrat $\mathrm{p}$ nitrofenil- $\alpha$-D-glukopiranosida (PNPG) dan pembanding akarbosa dengan menggunakan instrumen berupa Enzyme-Linked Immunosorbent Assay (ELISA reader). ELISA reader merupakan salah satu instrumen yang cara kerjanya mirip dengan spektrofotometer UV-Vis dengan sensitivitas dan spesifitas yang lebih tinggi. Pada umumnya ELISA digunakan sebagai metode atau teknik biokimia dengan prinsip reaksi kompleks antigen-antibodi dengan melibatkan peran enzim dan substrat sebagai indikator dalam reaksi. ${ }^{8}$ Berdasarkan dari beberapa uraian diatas dilakukanlah penelitian ini untuk memberikan informasi kepada masyarakat mengenai pemanfaatan biji alpukat sebagai antidiabetes serta cara pengolahannya yang benar dan efektif.

\section{METODE PENELITIAN}

\section{Alat dan Bahan}

Alat yang digunakan adalah batang pengaduk, bejana maserasi, blender (Philips $\left.{ }^{\circledR}\right)$, cawan porselin, corong Buchner, ELISA reader (Biotek $\left.{ }^{\circledR}\right)$, gelas arloji, gelas kimia (Phyrex®), gelas ukur (Phyrex®), labu takar (Phyrex®), lemari pendingin, pinset, pipet microliter (Eppendorf®), pipet tetes (Pyrex®), pipet volume (Phyrex®), pisau, sendok tanduk, timbangan analitik (Ohaous $\left.{ }^{\circledR}\right)$, vial, wajan, dan waterbath. Sedangkan bahan yang digunakan adalah akarbosa, akuades, a-Glukosidase yang berasal dari rekombinan Saccharomyces cerevisiae (Sigma Aldrich, USA), etanol 96\%, larutan dapar fosfat $\mathrm{pH} 7$, larutan $\mathrm{Na}_{2} \mathrm{CO}_{3}$ (Sigmaaldrich, USA), substrat $p$-nitrofenil-a-Dglukopiranosida (PNPG) (Wako Pure Chemical Industries, Ltd., Jepang) dan biji alpukat (Persea americana Mill.) yang telah disangrai dalam bentuk ekstrak dengan metode maserasi.

\section{Prosedur Kerja}

\section{Penyiapan bahan larutan}

Prosedur penyiapan bahan uji ini berdasarkan penelitian dari Djamil \& Utami $(2016)^{9}$ yang telah dimodifikasi.

Larutan Natrium Karbonat $\left(\mathrm{Na}_{2} \mathrm{CO}_{3}\right) \mathbf{2 0 0} \mathrm{mM}$. $\mathrm{Na}_{2} \mathrm{CO}_{3}$ ditimbang sebanyak $5,3 \mathrm{~g}$ kemudian dilarutkan dalam $250 \mathrm{~mL}$ air bebas $\mathrm{CO} 2$ hingga diperoleh konsentrasi $200 \mathrm{mM}$.

Larutan Akarbosa. Akarbosa ditimbang sebanyak $1 \mathrm{mg}$ dan dilarutkan dalam $100 \mathrm{~mL}$ dapar fosfat $\mathrm{pH}$ 7. Diperoleh larutan konsentrasi $10 \mathrm{ppm}$. Setelah itu dibuat dalam 
Uji Aktivitas Penghambatan Enzim A-Glukosidase Ekstrak Etanol Biji Buah Alpukat Sangrai ( americana Mill.) Secara in vitro

lima variasi konsentrasi yaitu 0,2 ppm, 0,4 ppm, 0,6 ppm, 0,8 ppm, dan 1 ppm.

Larutan Ekstrak Biji Alpukat. Ekstrak ditimbang sebanyak $10 \mathrm{mg}$ dan dilarutkan dalam $10 \mathrm{~mL}$ dapar fosfat $\mathrm{pH} 7$ hingga homogen. Diperoleh larutan induk konsentrasi $1000 \mathrm{ppm}$. Setelah itu dibuat dalam lima variasi konsentrasi yaitu 100, 125, 150, 175, dan 200 ppm.

\begin{tabular}{|c|}
\hline 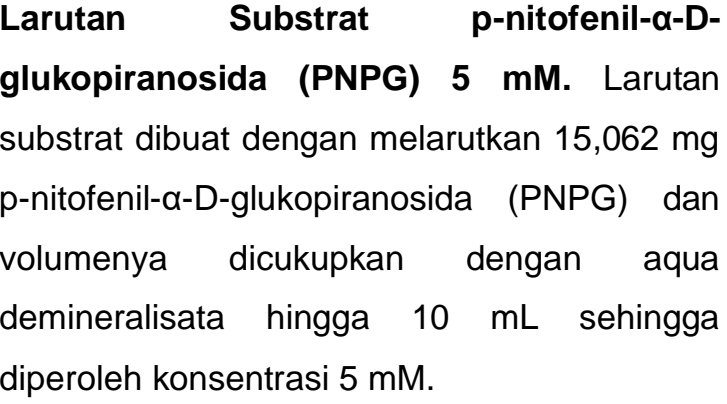 \\
\hline
\end{tabular}

\section{Larutan Enzim a-glukosidase}

Larutan Induk. Enzim a-glukosidase ditimbang sebanyak $1 \mathrm{mg}$ dan dilarutkan dalam $100 \mathrm{~mL}$ dapar fosfat $\mathrm{pH} 7$ (dalam setiap mg terdapat 28 $U)$.

Larutan Enzim $0,25 \mathrm{U} / \mathrm{mL}$. Larutan induk dipipet $0,089 \mathrm{~mL}$ dan volumenya dicukupkan hingga $10 \mathrm{~mL}$ dengan dapar fosfat $\mathrm{pH} 7$.

\section{Uji Penghambatan Aktivitas Enzim $\alpha-$ glukosidase}

\section{Pengujian Blanko}

Dapar fosfat $\mathrm{pH} 7$ sebanyak $36 \mu \mathrm{L}$ dan substrat p-nitrofenil- $\alpha$-D-glukopiranosida (PNPG) $5 \mathrm{mM} 17 \mu \mathrm{L}$ dimasukkan kedalam well dan diinkubasi pada waterbath selama 5 menit pada suhu $37^{\circ} \mathrm{C}$. Setelah masa inkubasi selesai, enzim a-glukosidase sebanyak $17 \mu \mathrm{L}$ ditambahkan kedalam well dan diinkubasi lagi pada waterbath selama 15 menit pada suhu 37C. Setelah masa inkubasi kedua selesai, $\mathrm{Na}_{2} \mathrm{CO}_{3} 200$ mM ditambahkan sebanyak 100 $\mu \mathrm{L}$ untuk menghentikan reaksi dan diukur absorbansinya dengan alat ELISA reader pada panjang gelombang $405 \mathrm{~nm}$.

\section{Pengujian Kontrol Blanko}

Dapar fosfat $\mathrm{pH} 7$ sebanyak $36 \mu \mathrm{L}$ dan substrat p-nitrofenil- $\alpha$-D-glukopiranosida (PNPG) $5 \mathrm{mM}$ sebanyak $17 \mu \mathrm{L}$ dimasukkan kedalam well, kemudian diinkubasi pada waterbath selama 20 menit pada suhu $37 \mathrm{C}$. Setelah masa inkubasi selesai, $\mathrm{Na2CO} 200$ mM ditambahkan sebanyak $100 \mu \mathrm{L}$ unt reaksi. Absorbansinya diukur dengan alat ELISA reader pada panjang gelombang $405 \mathrm{~nm}$.

\section{Pengujian Pembanding (Akarbosa)}

Dapar fosfat $\mathrm{pH} 7$ sebanyak $36 \mu \mathrm{L}$ dimasukkan kedalam well, kemudian pembanding dengan konsentrasi 0,2 ppm sebanyak $30 \mu \mathrm{L}$ dimasukkan kedalam well, begitu juga untuk pembanding dengan konsentrasi 0,4 ppm, 0,6 ppm, 0,8 ppm, dan 1 ppm. Substrat $p$-nitrofenil- $\alpha$-D-glukopiranosida (PNPG) $5 \mathrm{mM}$ ditambahkan sebanyak $17 \mu \mathrm{L}$ dan diinkubasi pada waterbath selama 5 menit pada suhu $37 \mathrm{C}$, setelah masa inkubasi selesai enzim $\alpha$-glukosidase ditambahkan sebanyak $17 \mu \mathrm{L}$ pada masing-masing well dan diinkubasi lagi pada waterbath selama 15 menit pada suhu $37 \mathrm{C}$. Setelah masa inkubasi selesai, Na2CO3 200 mM ditambahkan sebanyak 100 $\mu \mathrm{L}$ untuk menghentikan reaksi. Sampel kemudian diukur absorbansinya dengan alat ELISA reader pada panjang gelombang 405 $\mathrm{nm}$.

\section{Pengujian Kontrol Pembanding}

Dapar fosfat $\mathrm{pH} 7$ sebanyak $36 \mu \mathrm{L}$ dimasukkan kedalam well, kemudian pembanding dengan konsentrasi 0,2 ppm sebanyak $30 \mu \mathrm{L}$ dimasukkan kedalam well, begitu juga untuk pembanding dengan konsentrasi 0,4 ppm, 0,6 ppm, 0,8 ppm, dan 1 ppm. Substrat $p$-nitrofenil- $\alpha$-D-glukopiranosida (PNPG) $5 \mathrm{mM}$ ditambahkan sebanyak $17 \mu \mathrm{L}$ dan diinkubasi pada waterbath selama 20 menit 
Uji Aktivitas Penghambatan Enzim A-Glukosidase Ekstrak Etanol Biji Buah Alpukat Sangrai (Persea americana Mill.) Secara in vitro

pada suhu $37^{\circ} \mathrm{C}$. Setelah masa inkubasi selesai, $\mathrm{Na}_{2} \mathrm{CO}_{3} 200 \mathrm{mM}$ ditambahkan sebanyak 100 $\mu \mathrm{L}$ untuk menghentikan reaksi. Sampel kemudian diukur absorbansinya dengan alat ELISA reader pada panjang gelombang 405 $\mathrm{nm}$.

\section{Pengujian Sampel (Ekstrak etanol biji alpukat sangrai)}

Dapar fosfat $\mathrm{pH} 7$ sebanyak $36 \mu \mathrm{L}$ dimasukkan kedalam well, kemudian ekstrak etanol biji alpukat sangrai dengan konsentrasi 100 ppm sebanyak $30 \mu \mathrm{L}$ dimasukkan kedalam well, begitu juga untuk ekstrak etanol biji alpukat konsentrasi 125 ppm, 150 ppm, 175 ppm, dan 200 ppm. Substrat p-nitrofenil-a-Dglukopiranosida (PNPG) $5 \mathrm{mM}$ ditambahkan sebanyak $17 \mu \mathrm{L}$ dan diinkubasi pada waterbath selama 5 menit pada suhu $37 \mathrm{C}$, setelah masa inkubasi selesai, enzim a-glukosidase ditambahkan sebanyak $17 \mu \mathrm{L}$ pada masingmasing well dan diinkubasi lagi pada waterbath selama 15 menit pada suhu $37 \mathrm{C}$. Setelah masa inkubasi selesai, $\mathrm{Na}_{2} \mathrm{CO}_{3} 200 \mathrm{mM}$ ditambahkan sebanyak $100 \mu \mathrm{L}$ untuk menghentikan reaksi. Sampel kemudian diukur absorbansinya dengan alat ELISA reader pada panjang gelombang $405 \mathrm{~nm}$.

\section{Pengujian Kontrol Sampel}

Dapar fosfat $\mathrm{pH} 7$ sebanyak $36 \mu \mathrm{L}$ dimasukkan kedalam well, kemudian ekstrak etanol biji alpukat sangrai dengan konsentrasi 100 ppm sebanyak $30 \mu \mathrm{L}$ dimasukkan kedalam well, begitu juga untuk ekstrak etanol biji alpukat konsentrasi 125 ppm, 150 ppm, 175 ppm, dan 200 ppm. Substrat p-nitrofenil-a-Dglukopiranosida (PNPG) $5 \mathrm{mM}$ ditambahkan sebanyak $17 \mu \mathrm{L}$ dan diinkubasi pada waterbath selama 20 menit pada suhu $37^{\circ} \mathrm{C}$, setelah masa inkubasi selesai, $\mathrm{Na} 2 \mathrm{CO} 3200 \mathrm{mM}$ ditambahkan sebanyak $100 \mu \mathrm{L}$ untuk menghentikan reaksi. Sampel kemudian diukur absorbansinya dengan alat ELISA reader pada panjang gelombang $405 \mathrm{~nm}$.

\section{HASIL DAN PEMBAHASAN}

Tabel 1. Hasil Persen Rendamen Ekstrak Etanol Biji Buah Alpukat Sangrai (Persea americana Mill.)

\begin{tabular}{ccccc}
\hline Sampel & $\begin{array}{c}\text { Bobot sebelum } \\
\text { ekstraksi (g) }\end{array}$ & $\begin{array}{c}\text { Jumlah pelarut } \\
\text { (L) }\end{array}$ & $\begin{array}{c}\text { Bobot ekstrak } \\
\text { (g) }\end{array}$ & \% rendamen \\
\hline $\begin{array}{c}\text { Biji Buah } \\
\text { Alpukat Sangrai }\end{array}$ & 198,03 & 1,2 & 23,34 & 11,78 \\
\hline
\end{tabular}

Tabel 2. Hasil Penghambatan Aktivitas Enzim a-glukosidase oleh Pembanding dan Ekstrak Etanol Biji Buah Alpukat Sangrai (Persea americana Mill.).

\begin{tabular}{ccccc}
\hline Nama & $\begin{array}{c}\text { Konsentrasi } \\
(\mathbf{p p m})\end{array}$ & Absorbansi & $\%$ Inhibisi & $\mathbf{I C}_{\mathbf{5 0}}(\boldsymbol{\mu g} \mathbf{m} \mathbf{m L})$ \\
\hline & 0,2 & 0,33 & 48,995 & \\
Pembanding & 0,4 & 0,3 & 53,632 & \\
(akarbosa) & 0,6 & 0,271 & 58,114 & 0,253 \\
& 0,8 & 0,239 & 63,060 & \\
& 1 & 0,201 & 68,933 & \\
Ekstak Biji Buah & 100 & 0,266 & 64,199 & \\
Alpukat Sangrai & 125 & 0,239 & 67,833 & \\
& 150 & 0,193 & 74,024 & 34,300 \\
& 175 & 0,153 & 79,407 & \\
\hline
\end{tabular}


Uji aktivitas penghambatan enzim $\alpha$ glukosidase dari ekstrak etanol biji buah alpukat sangrai (Persea americana Mill.) bertujuan untuk mengetahui potensi dari ekstrak yang digunakan sebagai antidiabetes berdasarkan nilai $\mathrm{IC}_{50}$. Pada penelitian ini dipilih biji alpukat sebagai sampel dikarenakan hanya dijadikan limbah padahal secara empiris biji alpukat dipercaya dapat mengobati penyakit diabetes melitus (DM) tipe II. Adapun hasil ekstrak dan persen rendamen yang dihasilkan dapat dilihat pada tabel 2. Penentuan rendamen ini berfungsi untuk mengetahui kadar metabolit sekunder yang terbawa oleh pelarut tersebut namun tidak dapat menentukan jenis senyawa yang terbawa oleh pelarut. ${ }^{10}$

Pada penelitian ini menggunakan akarbosa sebagai pembanding, dimana akarbosa adalah oligosakarida yang diperoleh dari proses fermentasi Actinoplanes uthahensis yang bekerja menghambat enzim $\alpha$ glukosidase yang terletak pada dinding usus halus. Digunakan juga substrat $p$-nitrofenil- $\alpha$-Dglukopiranosida sebagai model yang mempresentasikan karbohidrat dalam tubuh, dimana enzim akan memecah substrat menjadi glukosa dan p-nitrofenol. Sesuai dengan prinsip dari pengujian ini yaitu pengukuran aktivitas enzim berdasarkan hasil absorbansi pnitrofenol yang merupakan hasil hidrolisis dari substrat p-nitrofenil- $\alpha$-D-glukopiranosida (PNPG). Semakin tinggi kemampuan komponen tanaman dalam menghambat enzim $\alpha$-glukosidase maka semakin kecil pula produk p-nitrofenol yang terbentuk yang ditandai dengan perubahan warna pada substrat yaitu warna kuning yang memudar. Telah diketahui bahwa enzim merupakan protein yang bersifat termolabil sehingga dalam pengerjaannya, suhu dan $\mathrm{pH}$ harus dijaga dalam keadaan optimum. Suhu yang digunakan yaitu $37^{\circ} \mathrm{C}$ dan $\mathrm{pH} 7$, maka dari itu digunakan dapar posfat $\mathrm{pH}$ 7 sebagai pelarut.

Dalam pengukurannya, digunakan instrumen Enzyme-Linked Immunosobent Assay (ELISA reader) dan diukur pada panjang gelombang $405 \mathrm{~nm}$. ELISA reader memiliki kelebihan yaitu dalam teknik pengerjaan yang relatif cepat, sensitivitas tinggi, serta hasil yang lebih akurat walaupun larutan uji yang igunakan dalam jumlah sangat kecil. ${ }^{11}$

Adapun hasil uji aktivitas penghambatan dapat dilihat pada Tabel 2. Nilai persen inhibisi yang didapatkan digunakan untuk menghitung nilai $\mathrm{IC}_{50}$ (konsentrasi yang dibutuhkan untuk menghambat $50 \%$ aktivitas enzim) dari sampel maupun pembanding dan nilai $\mathrm{IC}_{50}$ tersebut digunakan untuk mengetahui kekuatan penghambatan ekstrak terhadap enzim. Semakin rendah nilai $I_{50}$ maka kemampuan penghambatannya terhadap aktivitas a-glukosidase semakin tinggi, begitupun sebaliknya.

Nilai IC S0 $_{50}$ pada sampel sebesar 34,300 $\mu \mathrm{g} / \mathrm{mL}$ sedangkan pada pembanding sebesar $0,253 \mu \mathrm{g} / \mathrm{mL}$. Seperti yang dikutip dari penelitian Suhaenah $(2016)^{12}$ bahwa tingkat kekuatan inhibisi terhadap enzim a-glukosidase dikatakan sangat aktif jika IC $\mathrm{I}_{50} \leq 25 \mu \mathrm{g} / \mathrm{mL}$, aktif jika $25 \mu \mathrm{g} / \mathrm{mL} \leq \mathrm{IC}_{50} \leq 50 \mu \mathrm{g} / \mathrm{mL}$, kurang aktif jika $50 \mu \mathrm{g} / \mathrm{mL} \leq \mathrm{IC}_{50} \leq 100 \mu \mathrm{g} / \mathrm{mL}$, dan tidak aktif jika $\mathrm{IC}_{50}>100 \mu \mathrm{g} / \mathrm{mL}$. Berdasarkan kutipan tersebut, sampel ekstrak biji alpukat sangrai termasuk dalam kategori aktif dalam menghambat enzim $\alpha$-glukosidase, sedangkan pembanding (akarbosa) termasuk dalam kategori sangat aktif.

Berdasarkan hasil yang didapatkan menunjukkan bahwa ekstrak etanol biji alpukat 
sangrai mempunyai aktivitas dalam

menghambat enzim $\alpha$-glukosidase, hal ini tidak terlepas dari senyawa kimia yang dikandunganya. Salah satu senyawa kimia yang terkandung pada biji alpukat yang dipercaya dapat menghambat enzim $\alpha$ glukosidase yaitu flavonoid. Penelitian yang telah dilakukan oleh Tadera dkk $(2006)^{5}$ telah membuktikan secara in vitro bahwa flavonoid merupakan senyawa yang berpotensi menghambat $\alpha$-glukosidase.

\section{KESIMPULAN}

Berdasarkan hasil penelitian yang dilakukan dapat disimpulkan bahwa ekstrak etanol biji alpukat sangrai (Persea americana Mill.) memiliki aktivitas penghambatan dalam kategori aktif dengan nilai $I_{50} 34,300 \mu \mathrm{g} / \mathrm{mL}$.

\section{DAFTAR PUSTAKA}

1. Corwin and Elizabeth J. Buku saku Patofisiologi edk 3. Jakarta :EGC, 2009. pp 624.

2. Si MM, Lou JS, Zhou CX Shen JN, Wu HH, Yang B, He QJ and Wu HS. Insulin releasing and alpha-glucosidase inhibitory activity of ethyl acetate fraction of Acorus calamus in vitro and in vivo. Journal of Ethnopharmacology. 2010;128:(154-159).

3. Marlinda $M$, Sangi $M$ and Wuntu $A D$. Analisis Senyawa Metabolit Sekunder dan Uji Toksisitas Ekstrak Etanol Biji Buah Alpukat (Persea americana Mill.). Journal MIPA UNSRAT.2012;1(1):24-28.

4. Yuefei $W$, Shuangru $H$, Shuhong $S$, Lisheng $Q$ and Ping $X$. Studies on bioactivities of tea (Camellia sinensis L.) fruit peel extracts: Antioxidant activity and inhibitory potential against alphaglucosidase and alpha- amylase in vitro. Industrial Crops and Products. 2012;37(1):520-526.
5. Tadera K, Minami Y, Takamatsu $\mathrm{K}$ and Matsuoka. Inhibition of alpha-Glucosidae and alpha-amylase by Flavonoids. Journal of Nutritional Science and Vitaminology. 2006;52(2):149-153.

6. Shinde J, Taldone $\mathrm{T}$, Barletta $\mathrm{M}$, Kunaparaju N, Bo H and Kumar S. AlphaGlucosidase inhibitory activity of Syzygium cumini (Linn.) Skeels seed kernel in vitro and in Goto-Kakizaki (GK) rats'. Carbohydrate Research. 2008;343(7):1278-1279.

7. Nurhijrah. Uji aktivitas penghambatan Enzim alfa-glukosidase ekstrak metanol biji alpukat (Persea americana Mill.). menggunakan ELISA reader (Skripsi). Makassar: Fakultas Farmasi, Universitas Muslim Indonesia, 2016.

8. Layla Z and Poerwadikarta MB. Teknik Uji Aglutinasi cepat dan Enzyme Linked Immunosorbent Assay (ELISA) Untuk mendeteksi Antibodi Mycoplasma Gallisepticuml. Bogor : Balai penelitian veteriner, 2004.

9. Djamil R \& Utami KN. Uji Penghambatan Enzim a-Glukosidase Secara In-Vitro Dari Ekstrak Etanol 70\% Daun Leunca (Solanum nigrum L.). Rakernas \& PIT IAI. 2016. pp 1-8.

10. Ahmad AR, Juwita J, Ratulangi SAD dan Malik A. Penetapan Kadar Fenolik Dan Flavonoid Total Ekstrak Metanol Buah Dan Daun Patikala (Etlingera Elatior (Jack) Rm Sm) Menggunakan Spektrofotometri UvVis. Pharmaceutical Sciences And Research. 2016;2(1):1-10.

11. Sino Biological. ELISA encyclopdia (Internet). http://www.elisaantibody.com/ELISA-introduction. 2017 (Cited 10 March 2017).

12. Suhaenah A. Uji Aktivitas Antioksidan Ekstrak Jamur Kancing (Agaricus Bisporus) dan Efek Inhibisinya Terhadap Enzim Alfa-Glukosidase (Tesis). Makassar: Program Pasca Sarjana Universitas Hasanuddin, 2016. 